for the first time would be enhanced if less prominence were given to formal definition and more to simple explanation, but there is no doubt about the usefulness of this book to the student who wishes expeditiously to revise and amplify previous work. It is concise, well indexed, and contains a large number of exercises. Some of the latter might profitably be revised. The statement in Exercise 5 on p. I3 that in a certain fertiliser " $43 \frac{3}{4}$ per cent. is phosphoric acid (phosphorus)" will doubtless annoy the chemist. In the same exercise the student is asked to calculate how much acid phosphate containing 16 per cent. phosphoric acid is required, when mixed with cotton seed meal and kainit, to provide a mixture containing $43^{\frac{3}{4}}$ per cent. phosphoric acid. A practicable answer to this question might be the salvation of agriculture.

Unfortunately the use of American data and money units detracts from the value of the book to students elsewhere.

N. M. C.

(I) A Canadian School Geography. By Prof. G. A. Cornish. Pp. xiv $+45^{\circ}$. n.p. (2) The Canadian School Atlas. Prepared at the Edinburgh Geographical Institute under the Editorship of Prof. G. A. Cornish. Pp. v+65 maps $+\mathrm{r} 6$. n.p. (Toronto: J. M. Dent and Sons, Ltd., I922.)

(I) THE best features of this work are the maps, illustrations, and practical exercises. For the rest the book is planned on somewhat orthodox lines. Too much is attempted in the space available, so that in places the book gives little more than a catalogue of uncorrelated facts. It is certainly most informative, especially with regard to Canada, to which a large part of the book is devoted, but on the whole the geographical outlook is wanting.

(2) The atlas was prepared in the first instance to be used with this text-book, but may easily make a wider appeal as a general reference atlas for use in Canada. It contains forty-eight pages of finely executed maps by Bartholomew and a full index. Fourteen pages are devoted to maps of Canada, of which the most populated parts are shown on scales of $x: 2,500,000$. The rest of the world is shown on small-scale maps, but there is a coloured orographical map of every continent. One improvement would be the addition of a larger scale map of India, but the atlas as a whole deserves high praise.

Nyasa, the Great Water : being a Description of the Lake and the Life of the People. By the Ven. William Percival Johnson. Pp. vii +204. (London: Oxford University Press, I922.) $7 s .6 d$. net.

In this volume, the Archdeacon of Nyasa has placed on record his knowledge of the lake and its people, among whom he has served for many years as a member of the Universities' Mission to Central Africa. In the preface, the Bishop of Oxford, with pardonable enthusiasm, says that it is unique and "a book which no student of 'backward' races can afford to leave unread." Its readers, perhaps, will not be prepared to go so far ; but it is certainly a valuable and intimate study of the life and mentality, the customs, occupations, and beliefs of the Angoni, Wa Yao and Nyasa or Nyanza who live on the shores of the great lake Nyasa. The salient feature of the book is its keen insight into the native mind-a result which is achieved most markedly by means of the chapter of "village stories," in which the author has reported, in the words of the natives themselves, incidents of courage and helpfulness in the face of known and concrete danger. These he contrasts with the fear, leading to cruelty, arising out of the impalpable and unknown, which lies at the root of much of their religious ritual and belief.

Into the East: Notes on Burma and Malaya. By R. Curle. Pp. xxxi+224. (London: Macmillan and Co. Ltd., I923.) ros. net.

"CrTiEs (like persons)," says the author of this work, " have their idiosyncrasies that, slowly revealing themselves, layer upon layer, absorb you at last into their atmosphere," and goes on to ask what it is that the new-comer feels about Rangoon, in this particular instance, that to an inhabitant is second nature. Wherever his travels in the East have taken him, his purpose has been to seize the essentially differentiating quality in each place. He speaks of his book as a record of things seen and of things thought; but in the mind of the reader the latter will loom larger than the former, and in the retrospect, whether the author's words describe Colombo, Rangoon, Mandalay, the mining town of Kuala Lumpur, or the investiture of the Sultan of Perak with the K.C.M.G., it is their quality as an intensely personal record of impressions rather than as a statement of fact that will remain. In the end the author confesses himself baffled by the East, and its inscrutability and aloofness is perhaps the most vivid of the impressions he conveys to his readers. Mr. Joseph Conrad contributes a preface in which he discourses in characteristically alluring manner of ravellers and of their works.

Abrégé de géographie physique. Par Prof. E. de Martonne. Pp. v +355 . (Paris: Armand Colin, I922.) I5 francs.

STUDENTS of geography will be glad to have this outline summary of M. de Martonne's well-known "Traité de géographie physique." The general plan is the same as in the larger work, but a new chapter has been added giving a sketch of the relations of human and physical geography. In order to make the treatment throughout the book as concrete as possible, the author has chosen under each heading the most striking aspects of the subject, wisely making no attempt to cover all the ground in a limited number of pages. The third section, "le relief du sol," is particularly lucid, and is illustrated by most instructive photographs and block diagrams. The bibliographical references to each section are well chosen, but why is there no index ?

\section{The Practical Electrician's Pocket Book for 1923.} Twenty-fifth Annual Issue. Edited by H. T. Crewe. Pp. xci + 57 I + Diary. (London: S. Rentell and Co., Ltd., I923.) 3s. net.

A CHAPTER on "wireless" broadcasting has been added to this useful little book. Apparently some experimenters have difficulty in getting a good " earth," but the suggestion that they should get an old bath, solder the earth wire to it and then bury it, is in our opinion quite unnecessary.

$$
\text { NO. } 2804, \text { VOL. } 112]
$$

